\title{
TÜRKÇEDE BAĞDAŞIKLIK VE BAĞDAŞIKLIK UNSURLARI: KÜRK MANTOLU MADONNA İNCELEMESI
}

\author{
Araştırma Makalesi / Research Article
}

Hirik, S. (2020). Türkçede Bağdaşıklık ve Bağdaşıklık Unsurları: Kürk Mantolu Madonna İncelemesi. Nevşehir Hacı Bektaş Veli Üniversitesi SBE Dergisi, 10(1), 221-238.
Geliş Tarihi: 04.05.2020

Kabul Tarihi: 09.06.2020

E-ISSN: 2149-3871

Dr. Öğr. Üyesi Seçil HỉiIK

Nevşehir Hacı Bektaş Veli Üniversitesi, Eğitim Fakültesi, Türkçe ve Sosyal Bilimler Eğitimi Bölümü

secilhirik@nevsehir.edu.tr

ORCID No: 0000-0002-2698-9350

\begin{abstract}
öz
Tümce üstü birim olarak kabul edilen metin, göndericinin bağlamla beslediği ve alıcının da bağlamdan hareketle çözümlediği söz dizimsel ve anlambilimsel yapıdır. Tek bir sözcükten, sözcük öbeğinden veya tümcelerden bütün bir paragrafa kadar tüm yapılar, metin olarak kabul edilebilir. Metindilbilim ise temel malzemesi metin olan, metnin biçimsel ve içerik özelliklerini, verilen bilgilerin doğruluk değerini, tümceden ayıran yapısını ele alan bir disiplindir. Metindilbilimde iletişim ve bildirişim aracı olarak görülen metni, tümceden ayıran özellikler ve metinsellik ölçütleri ile ilgili farklı görüşler ortaya atılmıştır. Bunlar içinde en kabul gören Beaugrande ve Dressler'in (1981) yaptığı sınıflandırmadır. Buna göre yedi metinsellik ölçütünden bahsedilebilir: bağdaşıklık, tutarlılık, niyet, kabul edilebilirlik, durumsallık, metinlerarasıllk ve bilgisellik.

Metindilbilimsel bakış açısıyla Sabahattin Ali'nin Kürk Mantolu Madonna adlı eserinin incelendiği bu çalışmada metinsellik ölçütlerinden bağdaşıklık (coherence) ele alınmıştır. Bağdaşıklık, bir metnin derin yapısında yer alan ancak yüzey yapısında her seferinde gösterilmeyen ya da metinde akıcılı̆̆ı sağlamak için kullanılan ögeleri içermektedir. Bir metni bağdaşık kılmanın farklı yolları bulunmaktadır. Halliday ve Hasan’a (1976) göre bunlar gönderim, değiş̧tirim, eksilti, bağlaçlar ve sözcüksel bağdaşıkllktır. Kürk Mantolu Madonna adlı eserde bağdaşıklığı sağlayan şahıs adılları, dönüşlülük adılı, işaret adılı ve önadları, bir sözcüğün başka bir sözcük yerine kullanımı tespit edilmiş; özne, nesne, yüklem, tamlayıcı eksiltileri ile anlatıcı tekrara düşmekten kurtulmuştur. Yine metinde eş/yakın, zıt, üstanlamlı, genel anlamlı sözcük tekrarları ve eşdizimli sözcüklerle sözcüksel bağdaşıklık sağlandığı görülmüş̧ür.
\end{abstract}

Anahtar Kelimeler: Metindilbilim, Metinsellik Ölçütleri, Bağdaşıklık, Kürk Mantolu Madonna.

\section{COHESION AND COHESION ELEMENTS IN TURKISH: STUDY ON KÜRK MANTOLU MADONNA}

\footnotetext{
ABSTRACT

The text, which is accepted as a suprasentential, is a syntactic and semantic structure that the sender feeds with context and the receiver analyzes from the context. All structures, from a single word, phrase, or phrase to a whole paragraph, can be considered as text. Textlinguistics, on the other hand, is a discipline, which is the basic material of the text, which addresses the formal and content features of the text, the accuracy of the information provided, and its structure that distinguishes it from the sentence. Different opinions about the features that distinguish the text, which is seen as a communication and linguistic communication tool in textlinguistics, and the criteria for textuality have been put forward. The most accepted among these is the classification made by Beaugrande and Dressler (1981). According to Beaugrande and Dressler, seven criteria of textuality can be mentioned: cohesion, coherence, intentionality, acceptability, situationality, intertextuality, informativity.

In this study, where the text of Sabahattin Ali's Madonna in a Fur Coat (Kürk Mantolu Madonna) was examined from a textlinguistic perspective, cohesion, which is one of the textuality criteria, was discussed. Cohesion includes elements that are located in the deep structure of a text, but are not always shown in the surface structure, or used to ensure fluency in the text. There are different ways to make a text compatible.
} 
According to Halliday and Hasan (1976), these are reference, substitution, ellipsis, conjunctions and lexical cohesion. In the Sabahattin Ali's Madonna in a Fur Coat, it has been determined that the personal pronouns, reflexive pronouns, demonstrative pronouns and adjectives, and the use of a word instead of another word are provided. Thus, the narrator has been saved from falling into repetition with the subject, object, predicate and complementary ellipsis. In addition to them it has been observed in the text that there is a lexical cohesion with synonyms, opposite, regular, general meaningful word repetitions and collocations.

Keywords: Textlinguistics, Textual Criteria, Cohesion, Kürk Mantolu Madonna

\section{GÍRIŞ}

\subsection{Metin ve Metindilbilim}

Tümce üstü birim olarak tanımlanabilecek olan metin (text), konuşurun yalnızca sözcük dizmekten başka duygu ve düşüncelerini bağlamla beslediği söz dizimsel ve anlambilimsel birimdir. Metnin konuşurun yanı sıra dinleyici açısından da büyük bir değeri vardır. Tek bir sözcükten bile oluşabilecek olan metnin sözcelemede bir değer taşıyabilmesi için konuşur ve dinleyici yani gönderici ve alıcı arasında ortak kodlara sahip olması gerekmektedir. Metin bağlamsız düşünülemez. Bağlamdan kopuk metin, sözcük diziliminden başka bir şey değildir. Hem iletişim hem de bildirişimin parçası olan metin, söylemin yazılı ortamdaki karşılığı olarak algılanabilir.

M. Aksan ve Y. Aksan, çalışmalarında metin kavramının gündelik dildeki kullanım, bütüncül, bağıntısallık, bildirişim işlevi gibi işlevlerinin yanı sıra anlambilim özelliği ve gösterge yönü gibi farklı özelliklerini vurgulayan tanımlarını bir araya getirmiştir. Kimi araştırmacılar dil bilgisel biçimlerin ve ögelerin metin tanımlarının zorunlu bir bölümünü oluşturmasını savunurken kimileri de metinlerin yalnızca dil bilgisi ve mantık terimleriyle tanımlanamayacağını çünkü metin yapısının ve dil bilgisel kuruluşunun bağlam ve bildirişim ortamında kullanıcılar tarafından belirlendiğini savunur (1991: 94, 97, 98).

Parlak'a göre metinlerin merkeze alınması, metinlerin biçim ve içerik yönünden incelenmesi şeklinde gelişen süreç, metindilbilim bugünkü şeklini aldığında bir metnin dile ait unsurları nasıl kullandığı, onu tümceden ayıran ve tümceler üstü yapısını ortaya koyan kuralların neler olduğunu belirlemeye çalışmaktadır (2009: 4). Dilbilimsel bir süreç yaşayan metin incelemelerinde yapısalcılık, klasik söz dizimi, üretici dönüşümsel dil bilgisi gibi çalışmaların metindilbilimin oluşmasına yardımcı olan yaklaşımlar olduğunu söyleyen Aşkın Balcı, metindilbilimde tümce düzeyini aşan, dilin daha büyük birimleri üzerinde çalışma yapılması gerekliliğinin ortaya çıktığını söylemektedir. Kısaca metinle ilgili ilk çalışmalarda bağlamın göz ardı edildiği yaklaşımlar 1970 yılı sonrasında daha farklı bir anlayışa bırakmıştır. Buna göre dili anlamak, dili betimlemek, onu bağlam içinde kullanmayı gerektirmektedir düşüncesi yaygın hale gelmiş ve dilin iletişimsel ve edimsel yönü ağır basmaya başlamıştır (2018: 31-34; bk. Coşkun, 2005: 37, 39). Metin, Uzun'a göre artık yalnızca tümce temelli değil sosyolojik ve antropolojik etkenlerden beslendiği kabul edilen bir malzeme hâline gelmiştir. İletişim ortamının da dâhil edildiği daha kapsamlı bir yapı olarak düşünülmeye başlanan metin yalnızca bir ürün değil aynı zamanda bir süreç olarak algılanmaktadır $(2018: 5,16)$. Bir metnin metin kabul edilebilmesi için gerekli ölçütleri belirleyen, metinlerin daha anlaşılır olmasını sağlayan metindilbilim, metni bilgisel ve anlamsal yapısıyla iletişimsel boyutta ele almakta, tek tek tümceleri değil metin bütünüyle incelemektedir (Bozok, 2019: 9, 14; Oraliş ve Ozil, 1992: 37; Özkan, 2004: 170).

Araştırmacıların yaptıkları tanımlara bakıldığında görülmektedir ki metindilbilim, malzemesini metin olarak ele alan ve metni de tümceden üstün tutan bir disiplindir. Metnin tümceden farkı, metnin ne olması gerektiği, metni metin yapan özellikler, metin aktarımında kullanılacak ölçütler, metin aracılığıyla sosyolojik ve antropolojik çıkarımlarda bulunmaya çalışma, yazarı, metnin oluşturulduğu çevreyi tanıma ve yorumlama metindilbilimin cevabını aradığı konular arasındadır. Ancak tüm bu sorun ve konuların başında gelen nokta, yazılı bir dizgeye neye göre metin denileceği meselesidir. Bu sebepledir ki araştırmacılar öncelikle bir metni, metin yapan ölçütleri belirlemeye çalışmışlardır. Bunların başında Beaugrande ve Dressler'in (1981) öne sürmüş oldukları metinsellik ölçütleri gelmektedir. 


\subsection{Metinsellik Ölçütleri}

Beaugranda ve Dressler (1981: 26), yedi metinsellik ölçütünden bahsetmektedir: Bağdaşıklık, tutarlılık, niyet, durumsallık, bilgisellik, kabul edilebilirlik, metinlerarasılık ${ }^{l}$. Yüzey yapıların ayrı metinler arasında paylaşılması veya alıntılanılması durumuna bağdaşıklık (cohesion) denmektedir. Tek bir metnin tutarlılı̆̆ (coherence), sıklıkla bağdaşıklık ile karıştırılmaktadır ancak yüzeyin bağlayıcılığı ile altta yatan içeriğin bağlayıcılı̆̆ 1 arasında bir ayrım bulunmakla birlikte tutarlılık sadece genel söylem göz önüne alındığında daha belirgindir. Anlatıcının amacının yansıması olan niyet (intentionality), metnin hedefe yönelik kullanımı olarak düşünülmektedir. Okurun beklentisi ve anlatıcı ile okur arasındaki bilgi alışverişinde yaşantıların, kültürel unsurların ve ihtiyaçların ortak olması gerekliliği olarak da yorumlanabilecek olan kabul edilebilirlik (acceptability) metne yönelik anında geri bildirimde bulunulmasıdır. Durumsallığın (situationality) metin üzerinde belirli bir rolü bulunmaktadır ve Uzun'a göre metnin hedeflenen kitle, içinde bulunulan koşullar ve ulaşılmak istenen amaç dikkate alınarak oluşturulmasıdır (2018: 20). Metinlerarasılık (intertextuality), bir metnin diğer metinlerle ilişkisini göstermektedir ve iletişim sürecinde üretim ve alımlamanın bu sürece katılanların diğer metinlere ait bilgilerine bağlı olma durumudur. Bilgisellik (informativity), konuşurun metinden talebiyle doğru orantılı olarak karşılanmasıdır. Bir metnin okuyucunun ilgisini çekmede ve devam ettirmede başarılı olabilmesi için okura sunduğu yeni ve eski bilgilerin dengeli olması gerektiğini belirten Coşkun, okur için yeni olan bilgilerin çokluğu metnin anlaşılmasını zorlaştırabilir. Eski bilgilerin çokluğu ise metnin anlaşılma düzeyini arttırdığı hâlde, okunmaya değer olmamasına yol açabilir (2005: 46).

Metindilbilimsel ölçütlerden bağdaşıklık ve tutarlılık metindilbilimsel incelemelerde ana yapıyı ortaya koymada en çok başvurulan ölçütlerdir ve metin merkezli olmaları bakımından diğerlerinden ayrılmaktadır. Buna göre durumsallık, bilgisellik, kabul edilebilirlik niyet ve metinlerarasılık kullanıcı merkezli ölçütler arasında yer almaktadır.

\subsubsection{Bağdaşıklık}

Metnin yüzey yapısında gösterilenle derin yapısında yer alan bilgilerin dil bilgisel veya anlamsal yolla bağlantısını gösteren metinsellik ölçütüne bağdaşıklık denmektedir. Bir metin yüzey yapısında anlatıcısından bilgi, deneyim, kültürel ögeler vs. olmak üzere izler taşımakta ve kendi içinde de bilgiler arası örtüşmeleri yansıtmaktadır. Anlatıcı yani gönderici tarafindan iletilmek istenen mesajın niyete uygun ve kabul edilebilir olabilmesi için de bazı ölçütleri yerine getirmesi gerekmektedir. Aksi takdirde okur, verilmek istenen mesajı algılayamayacak, zihninde boşluklar kalmaya devam edecektir. Bununla birlikte bir metinde verilmek istenen tüm bilgilerin yüzey yapıda gösterilmesi mümkün değildir. Bunun için tümcelerin birbirlerine eklemlenerek bir metin oluşturmasını sağlayabilmek için uyulması gereken ölçütlerden bazıları doğrudan metnin yüzey yapısıyla, yani sözcük ve sözdizimi düzeyiyle ilgili olduğunu söyleyen Onursal, tüm bunların metnin kendi içinde uyumlu olmasını sağladığını belirtmektedir. (2011: 129, 130). Söz konusu uyum dil bilgisel, söz dizimsel ve anlamsal nitelikli olmak zorundadır.

Halliday ve Hasan, söylemdeki bazı unsurların yorumunun diğerininkine bağlı olmasının metnin bağdaşıklık özelliği olduğunu söylemektedir. Bu olduğunda, bir uyum ilişkisi kurulur ve bu durumda ön varsayım ve ön varsayım olan iki unsur, en azından potansiyel olarak bir metne entegre edilir. Bu, Halliday ve Hasan'a göre $b a \breve{g}$ (tie) kavramına yaklaşmanın başka bir yoludur. Bağdaşıklık, bir dil sisteminin bir parçasıdır. Bağdaşıklık potansiyeli, dilin içine yerleştirilmiş sistematik gönderim, eksilti ve benzeri kaynaklara uzanır. Diğer anlambilimsel ilişkiler gibi, bağdaşıklık da dilin katmanlı (stratal) düzenlenmesi yoluyla ifade edilir $(1976: 4,5)$.

Hem sözcük ve tümcelerin hem de bu öbek yapıları oluşturan tüm bağımlı ve bağımsız biçimbirimlerin arasında olan ilişki, yine tüm bu unsurların birbirini tamamlaması olarak yorumlanabilir. Bir metni oluşturan birimler (tümceler) arasındaki ilişkide görünen bu bağlar Beaugrande ve Dressler için yüzey metninin bileşenlerinin, yani duyulan veya görülen gerçek sözcüklerin bir dizi içinde karşılıklı olarak bağlanma yollarıla ilgilidir. Yüzey bileşenleri dil bilgisi

\footnotetext{
${ }^{1}$ Çalışmanın temel konusunun metinsellik ölçütlerinden bağdaşıklık olması sebebiyle bağdaşıklık kategorisine ayrıntılı olarak yer verilmiş olup diğer ölçütlerden genel hatlarıyla bahsedilmiştir.
} 
biçimlerine ve kurallarına göre birbirine bağlıdır ve bağdaşıklık dil bilgisel bağımlılıklara dayanmaktadır (1981: 11, 14, 53).

Metinde bağı sağlamak ya da bütünlüğü kurmak da verilen bilgilerin birbiriyle çeşitli yollarla örtüşmesi ile mümkündür. Metin merkezli yapı sergileyen bağdaşıklık, yüzey yapıda gösterilmeyen her unsurun açık veya örtük biçimde yine metinde karşılığının bulunmasını gerektirmektedir. Balyemez, iyi kurgulanmış metinlerde bir tümcelerin tam olarak anlaşılması ve yorumlanmasının kendisinden önceki veya sonraki tümcelerle doğrudan ilişkili olduğunu diğer bir deyişle metni meydana getiren tümcelerin değişik açılardan birbirine bağlandığını belirtmektedir. Örneğin "Çok hastaymış, eve gitti." şeklindeki anlamlı bir birimde iki tümce arasında bir mantık ve anlam bağlantısı vardır (2011: 24). Metnin yüzey yapısını ilgilendiren bağdaşıklık sadece tümceler arasında değil, paragraflar arasındaki bütünlüğü de sağlayan bir unsurdur (Seçkin vd., 2014: 341). Metindeki sözcüklerin ve tümcelerin birbirlerine aşamayla eklenmesinin metnin yüzeysel yapısındaki dil bilgisel ilişkiler yoluyla oluşan bağlantılarla ortaya çıktığını belirten Girmen, Seçkin ve diğerlerinin de vurguladığı gibi metindeki bağdaşıklık ilişkisinin bazen bir tümcenin içinde bazen tümceler arasında bazen de paragraflar arasında ortaya çıktığını vurgulamaktadır (2011: 47).

Halliday ve Hasan bağdaşıklığı, dil bilgisel ve sözlüksel bağdaşıklık olarak ikiye ayırır. Bu iki ayrımın varlığı anlamın dışlandığı anlamına gelmemektedir. Bağdaşıklık, anlamsal bir ilişkidir. Bazı bağdaşıklık biçimleri dil bilgisi, diğerleri sözcük dağarcığı yoluyla gerçekleşir. Bağdaşıklık, bir şeyi daha önce olanlarla ilişkilendirmek için var olan olasılıkları ifade eder. Bu bağlantı anlamda (meaning) ilişkiler aracılığı ile sağlandığından, söz konusu olan bu şekilde işlev gören anlam ilişkileri kümesidir (1976: 6-14).

Farklı çalışmalarda metin olma ölçütlerinden bağdaşık kılma yolları ile ilgili farklı sınıflandırmalar yapılmaktadır. Uzun Subaşı, Hasan ve Halliday'in sınıflandırmasını temel alarak onun gönderim, değiştirim, eksilti, bağlaç ve sözlüksel bağdaşıklık türlerinin yanı sıra zaman, görünüş ve kip kategorilerini de değiştirimin altında vermeyi uygun görmektedir. Bununla birlikte bağdaşıklık kategorilerini gönderimsel ve biçimsel-sözlüksel bağdaşıklık temel başlıkları altında toplamaktadır (1995: 35). Pek çok çalışmaya zemin oluşturması sebebiyle bu çalışmada Halliday ve Hasan'ın (1976: 6) bağdaşıklık kategorilerini içeren sınıflandırması temel alınmıştır. Buna göre dil bilgisel bağdaşıklık gönderim, değiştirim ve eksiltiden oluşurken sözlüksel bağdaşıklık, bağlaçlar ve sözcüksel bağdaşıklık ile sağlanmaktadır².

Türkçe üzerinde metinsellik ölçütlerinin incelendiği pek çok çalışma ${ }^{3}$ görülmektedir. $\mathrm{Bu}$ çalışmalardan kimi Türkçenin tarihi dönemlerinden seçilen metinler üzerinde gerçekleşirken kimisi de Türkiye Türkçesi ile yazılmış edebi metinler veya MEB müfredatında yer alan ders kitaplarında bulunan okuma parçalarına yönelik yapılmıştır.

Bu çalışmada Sabahattin Ali'nin Kürk Mantolu Madonna adlı romanı (Sabahattin Ali, 2019) örneklem olarak seçilmiştir. Sabahattin Ali'yi toplumsal gerçekçilik akımının sanatkâr hikâyecisi olarak tanımlayan Enginün, onun eserlerinde kadının çok yer tutuğunu dile getirmektedir. Kürk Mantolu Madonna' da da olduğu gibi yazarın toplum şartlarına yenik düşen bu kadınlara büyük bir acıma duyduğu hissedilmektedir (2005: 286, 287). Kürk Mantolu Madonna'da Raif Bey'le Maria Puder arasında önce tek taraflı bir başlayan aşk zamanla karşılıklı bir hal alır ve ikisi için de tek ve gerçek aşk budur, yaşamlarını bu aşkla tamamlarlar (Aydoğan, 2014: 77). Genel hatlarıyla bir aşkın hikâyesi olan bu eserde, Halliday ve Hasan'ın metinsellik ölçütlerinden bağdaşıklık unsurları ele alınmıştır. Buna göre gönderim, değiştirim, eksilti, bağlaçlar ve sözcüksel bağdaşıklık kategorilerine örnek teşkil eden hem morfolojik hem de sözlüksel unsurlar metinde geçen temsili örneklerle sunulmuştur.

\subsubsection{Gönderim}

Dilin ekonomik ve akıcı olarak kullanılmasını sağlamak, metindeki konuları alımlayan kişinin beyninde aktif tutmak ve metinde konu bütünlüğünü oluşturmak için metin içindeki bazı sözcük, kavram, düşünce ya da izleğe metin boyunca farklı dilsel ögelerle yineleneme yoluyla

\footnotetext{
${ }^{2}$ Daha fazla bağdaşıklık sınıflandırması için ayrıca bk. Uzun Subaşı (1995), Aşkın Balcı (2018), Torusdağ ve Aydın (2019). ${ }^{3}$ Söz konusu çalışmalardan bazıları için bk. Uzun Subaşı (1995), Akçataş (2001), Aşkın Balcı (2006), Balyemez (2011), Y1lmaz (2012), Kala (2018), Bozok (2019).
} 
gönderimde bulunulur ve bu ögelere Dilidüzgün, gönderim ögeleri ${ }^{4}$ demektedir (2008: 58). Gönderim (reference), işaret edilen anlam ya da kavram alanının metinde farklı şekillerde yeniden görünmesini ifade eden bir kavramdır. Aynı sözcük, sözcük öbeği ya da tümcenin tekrar tekrar söylenmesi okur açısından anlamayı güçleştiren, okumada akıcıllğı bozan ve metnin vermek istediği mesajı sekteye uğratan bir durum teşkil ettiği için anlatıcı yani metin üreticisi, bunun yerine daha önce söylediklerinin yerine geçebilecek başka unsurlar yerleştirmeyi uygun görmektedir. Balyemez ve Akçataş'a göre gönderim, bir dil biriminin kendisinden önceki veya sonraki başka bir dil ve anlam biriminin yerini tutması, o birime işaret etmesi veya sözcük birimlerinin aynı kavram ve varlığı ifade etmesidir (2011: 29; 2001: 27).

Uzun Subaşı, gönderimde bulunulan birimlerin ad ya da ad öbekleri metin katılımcıları ya da durum ögeleri olduğunu belirtmektedir. Metne katılan adların/öbeklerin dil bilgisel olarak yinelenmesini sağlayan dilsel ögelerin sözlüksel anlamları yoktur (2004: 30). Ancak metinde gönderimde bulundukları öge ile beraber belirli bir anlam alanına işaret etmektedir.

Halliday ve Hasan, gönderim türlerini $i c ̧$ (textual) ve $d l$ ş (situational) gönderim (endophoric and exophoric reference) olarak ikiye ayırmaktadır. İç gönderim önceki metne gönderimde bulunan $\ddot{o n}$ (anaphora) ve takip eden metne gönderimde bulunan art (cataphora) gönderim olarak ikiye ayrılmaktadır. Ayrıca Halliday ve Hasan, gönderim türlerini kişisel (personal), gösterimsel (demonstrative) ve karşılaştırmalı (comparative) gönderim olmak üzere üç kategoride ele almaktadır (1976: 31-39).

Metin dıșı gönderimde ise gönderim yapılan unsur metnin dışında yer almaktadır. Doğrudan metne bir katkısı olmayan ve aslında okur açısından doğrudan bir değere sahip olmayan bu gönderim türünde anlatıcı genellikle metnin akışını bölerek okura seslenmektedir. Metin içi gönderimde gönderim yapılan tüm unsurlar ya gönderim yapan unsurdan önce ya da sonra metinde gelmektedir. Metin içi gönderimde ön ve art gönderim türleri gönderimde bulunulan ögeye göre değiş̧kenlik göstermektedir. Öngönderimde daha çok şahıs ve dönüşlülük adılları, gösterme adılları, gösterme önadları görülürken art gönderim ögeleri arasında iyelik ekleri, belirtme durum eki, ilgi eki ve şahıs ekleri yer almaktadır ${ }^{5}$. Söz konusu tüm birimlerin metinde bir karşılığı olduğu gibi gönderimde bulunulan öge de mutlaka bir varlık, durum ya da hareketi yerine geçmektedir. Aşağıda incelenen metinde, gönderimde bulunan unsur koyu renkle ve eğer metin içinde yer allyorsa gönderimde bulunulan unsur da altı çizili olarak gösterilmiştir.

\subsubsection{1. Öngönderim}

\section{a. Adıllarla Yapılan Gönderim}

\section{Sahıs Adıllarıyla Yapılan Gönderim}

Sabahattin Ali'nin bahsi geçen eserinde şahıs adıllarının sıkça gönderimde bulunmak için kullanıldığı dikkat çekmektedir. Özellikle 3. teklik şahıs ve 1. çokluk şahıs adıllarının diğer şahıslara göre varlığı daha belirgindir. Eserin anlatıcısı, olayı yaşayan ve aktaran kişi olması sebebiyle 1. şahıs adılını kullanmasına rağmen gönderimde bulunulan ögeden yani kendi kimliğinin ne olduğundan bahsetmemektedir. Dolayısıyla ben ile yapılan gönderimlerde gönderim yapılan ögenin belirsizliği görülmektedir. Aşağıda metinde geçen şahıs adıllarıyla yapılan gönderimler yer almaktadır:

(1) Şimdiye kadar tesadüf ettiğim insanlardan bir tanesi benim üzerimde belki en büyük tesiri yapmıştır (2019: 7).

(2) Hamdi önünde serili duran bir sürü kâğıt ve içeri girip çıkan bir sürü memurla meşguldü (...) Şimdi onun karşısında hakikaten amirim, hatta velinimetimmiş gibi bir şaşkınlık duyuyor ve bu kadar alçalan benliğime bu muameleyi cidden laylk görüyordum (2019: 12).

(3) Biraz ötede, Raif efendinin baldızı Ferhunde, iki çocuğunu kucă̆ına oturtmuş, onların gürültü etmelerine mâni olmak için bir şeyler söylüyor, fakat her halinden, çocuk avutmanın ne kadar acemisi olduğu anlaşıllyordu (2019:38).

(4) Dün akşamdan beri ne Hamdi, ne de ben hakikatte değişmiş değildik; (...) bazı küçük ve teferruata ait şeyler bizi ayrı istikametlere alıp götürmüşlerdi (2019: 13).

\footnotetext{
${ }^{4}$ Aşkın Balcı, çalı̧̧masında gönderim ögeleri kavramı yerine gönderge demeyi tercih etmekte ve bir metinde aynı anlambilim özelliğine sahip eşgöndergeler arasındaki dilsel ifadeleri gösteren ve metin içindeki bağdaşıklığa katkıda bulunan yapılara da metindilbilimde gönderge ilişkisi adını vermektedir ( 2018: 64).

${ }^{5}$ Ayrıca bk. Torusdağ ve Aydın (2019: 94-95), Coşkun (2005: 53).
} 
(5) Biz șarklılar çok kibar insanlarızdır... (2019: 101)

\section{Dönüşlülük Adılı ile Gönderim}

Metinde dönüşlülük adılı kendi sözcüğünün farklı çekimlerle kullanıldığı görülmektedir. Adılın kullanıldığı tümcelerde gönderim yapılan unsur çoğunlukla tümcede yer almamaktadır.

(1) Böyle kimseleri gördüğ̈̈müz zaman çok kere kendi kendimize sorarız (2019: 7).

(2) Slk sık görüş̧ü̈g̈̈m Hamdi'yi, bankadan ayrıldı̆̆ımdan beri görmemiştim (...) Işsiz zamanımda kendisine müracaat etmeyişim de hemen hemen bunun içindi (2019: 9).

\section{İşaret Adılları ile Gönderim}

Şahıs adılları gibi işaret adılları da metinde gönderim amaçlı kullanılan unsurlar arasında görülmektedir. İşaret adıllarından $b u$ ve $o$ adılının çokluk kullanımlarıyla beraber metindeki varlıkları baskın orandadır. Şu adılı ise daha çok önad işlevinde metinde geçmektedir.

(1) Galiba zihninden "Buyurun, oturun!" demek geçti. Fakat sonra buna lüzum görmeyerek yavaşça dışarı süzüldü (2019: 10).

(2) Ertesi gün, öğleye doğru Hamdi'nin șirketine gittim (...) Benim klzgınlı̆̆ım Hamdi'ye değil, kendime de değil, sadece burada bulunuşumaydl (2019: 13).

(3) Başka servislerdeki memurlardan birçoğuyla tanışmış, hatta akşamüzeri beraber çıkarak bir kahvede tavla oynamaya bile başlamış̧tk. Bunlardan öğrendiğime göre, Raif efendi müessesenin en eski memurlarındandı (2019: 15).

(4) Sirkette olsun, evde olsun, kendisine ruhen tamamen yabancı insanlarin onu adamdan saymamalarını hos görmekle kalmiyor, bunda adeta bir nevi isabet de buluyordu (2019: 29).

(5) Işste beni o loş koridorda tutan ve oradan geçecek olan diğer hademeyi beklemeye sevk eden bunlardl (2019: 13).

(6) Sonra bu garip ăgaçlar bana daima hasretini çektiğim uzak memleketleri hatırlatır... Onların alıştıklar yerlerden sökülerek buraya getirildiğini ve böyle suni tedbirler, ihtimamlarla yaşatılmaya çalışıldığını gördükçe biraz da hallerine acırım (2019: 89).

(7) Annem, tabi olmaya, itaat etmeye alışmış olan kadınlı̆̆ın adeta bir timsaliydi (...) Yedi yaşında olduğum halde onu ben idare etmeye başladım (2019: 95).

\section{b. Önadlarla ile Gönderim}

$B u$, şu, o gibi işaret bildiren sözcüklerin adlarla birlikte kullanım örnekleri taranan metinde oldukça fazladır. Ancak aşağıda yer alan örnekler metindeki tüm işaret önadlı gönderimleri temsil edecek sayıda verilmektedir.

(1) Şimdiye kadar tesadüf ettiğim insanlardan bir tanesi benim üzerimde belki en büyük tesiri yapmıştır. Aradan aylar geçtiği halde bir türlü bu tesirden kurtulamadım (2019: 7).

(2) Her zaman ihmalkâr olmayan, hatta bu gibi kaidelere fazlaca dikkat eden ve hayattaki muvaffakiyetinin bir kısmını da bu dikkatine borçlu olan Hamdi'nin beni böyle ortada bıraklvermesinin sebebini düşündüm (2019: 10).

(3) Simdi ne diye arkasindan gidiyordum? Acaba o muydu? Gecenin herhangi bir saatinde bir sokaktan geçen bir kadının ertesi akșam gene ayn yerden geçmesi icap ettiğine nereden hükmediyordum? Bütün bu suallere cevap verecek halde değildim (2019: 65).

(4)Buna rağmen müdürün ve bizim Hamdi'nin Raif efendiye karşı muamelelerinde: "Bak, seni şu mızmız, hastalıklı haline rağmen atmlyoruz!” demek isteyen bir şey vardı (2019: 16).

(5) Nedense, hayatta bir müddet beraber yürüdügümüz insanların başına bir felaket geldiğini (...) o zavallılara, sanki bize de gelebilecek belaları kendi üstlerine çektikleri için, alaka ve merhamet göstermek isteriz (2019: 9).

\section{c. Eklerle Yapılan Gönderim Iyelik Ekli Gönderim}

Şahıs adıllarının kullanılmayıp iyelik bildiren eklerle herhangi bir varlığa gönderimde bulunulabilir. $\mathrm{Bu}$ kullanımı gösteren örneklerden bazıları taranan metinde aşağıdaki gibi geçmektedir: 
(1) Hamdi önünde serili duran bir sürü kâğıt ve içeri girip çıkan bir sürü memurla meşguldü. (...) Elini slkmaya cesaret edemeden iskemleye iliş̧tim (2019: 12).

(2) Küçük uçlara doğru sivrilen ve kemiklerinin gayet ince olduğu hissini veren parmakları vardı ve bunların ucu, üşümüş gibi, kırmızıydı (2019: 73).

(3) Hakikaten Raif efendiyle aramızda bugünden sonra bir yakınlı hâsıl oldu (2019: 23).

(4) Oldukça aklı başında bir insana benzeyen Necla ile, henüz ilk mektebe devam eden Nurten bile, ihtimal eniştelerinin, teyzelerinin ve dayllarının tesirleriyle, babalarına karşı umumi havaya uymuşlardı (2019: 27).

\section{Ayrllma Durum Ekli Gönderim}

Ayrılma durum ekinin çıkma/uzaklaşma/ayrılma bildiriyor olması işlevinden başka varlıkla ilgili çoklu benzerleri arasından seçim yapılırken biri ya da birilerine işaret etmek amacıyla kullanımına rastlanmaktadır. Aşağıda yer alan örneklerden ilkinde daire arkadaşlarından olan olayın baş kahramanlarından birine gönderimde bulunulmaktadır. Bunun için aynı zamanda eksiltili yapı da tercih eden anlatıcı "daire arkadaşlarından biri" demek yerine yalnızca ayrılma durum ekini kullanmaktadır.

(1) Nitekim araba beş on adım gittikten sonra durdu, kapısı açıldı; mektep arkadaşlarımdan Hamdi, başını uzatmış, beni çă̆ırıyordu (2019: 9)

(2) "Daire arkadaşlarından..." diye takdim etti. "Refikam." (2019: 22)

\subsection{Artgönderim}

Metinde artgönderimin aitlik eki ve iyelik ekleriyle yapıldığı görülmektedir. Gönderim yapılan öge ekin yer aldığı sözcükten sonra yer almaktadır.

(1) Pansiyondaki Hollandalı dul Frau Tiedemann da benimle ahbapliğı ilerletmiş̧ti (2019: 59).

(2) Evet, bu, birkaç dakika evvel şurada duran Hamdi'nin, daha doğrusu onun ruhunun resmiydi (2019: 19).

(3) Bir kenarda, kapısı yarı açık duran, vişneçürügü boyalı adi elbise dolabının içinde rastgele asılmış elbiseler, tayyörler ve bunların altında dügüumlü bohçalar vardı (2019: 21).

\subsubsection{Değiştirim}

Değiştirim (substitution), bir metinde yer alan ögelerden birinin başka bir birimle diğerini kapsamasıdır. Diğer bir deyişle bir ögenin başka ögenin yerine geçmesidir. Tıpkı gönderimde olduğu gibi tekrarların önüne geçmek için bir öge başkasıyla karşılanır. Ancak değiştirimin gönderimden farkı daha çok artgönderim yapılması ve karşılanan ögenin bir varlıktan ziyade bütün bir duruma işaret etmesidir. Halliday ve Hasan'a göre bu bağdaşıklık türünde üç tür değiştirim olduğundan bahsedilmektedir: ad, eylem ve yan tümce/tümce (1976: 91).

Kürk Mantolu Madonna adlı eserde çok sayıda değiştirim yoluyla bağdaşıklık kurulduğu dikkat çekmektedir. Bunun için biri/birbiri, ikimiz/ikisi, hepsi, herkes, öteki, böyle/öyle gibi sözcüklerle beraber ad türünden başka sözcüklerin de kullanıldığı görülmektedir. Bahsi geçen adıllar içerinde böyle adılı, anlatıcı tarafindan diğerlerine göre daha çok tercih edilmekle birlikte bir adın başka bir sözcükle karşılanması yoluyla yapılan değiştirim örnekleri de metinde çok sayıda geçmektedir.

\section{a. Biri/Birbiri Sözcü̈̆̈̈̈ ile Değiştirim}

(1) Raif efendinin saf yüzü, (...) gözlerimin önünde canlanıyor... Hatta pek alelade, hiçbir hususiyeti olmayan, her gün etrafimızda yüzlercesini görüp de bakmadan geçtiğimiz insanlardan biriydi (2019: 7).

(2)Diğer memurlara karşı daima daha ihtiyatlı olan ve her biri bir türlü iltimasa dayanan bu gençlerden fena bir mukabele görmekten çekinen arkadaşımın, kendisine asla mukabeleye cesaret edemeyeceğini bildiği Raif efendiyi bu kadar hırpalaması, (...) gayet kolay anlaşılabilirdi (2019: 16).

(3) Bir gün bana getirilecek kahve için klzlarının dışarıda birbirleriyle yavaş sesle: "Sen pişir!” (...) demişti (2019: 29). 
(4) Biz, hakikatte hep eskisi gibi birbirini arayan, isteyen, birbirinin huzurundan her zaman daha memnun ve zengin olarak dönen iki candan arkadaștık (2019: 108).

\section{b. İkimiz/ikisi Sözcü̆ğ̈ ile Değiștirim}

(1) Dün akşamdan beri ne Hamdi, ne de ben hakikatte değişmiş değildik (...) İş̧in asıl garip tarafi, ikimiz de bu değişikliği olduğu gibi kabul ediyor ve tabii buluyorduk (2019: 13).

(2) Bir müddet sustuk, ikimiz de belli etmeden birbirimizi tetkik etmek istiyor ve bu sirada gözlerimiz karşılaşıverince, "gördüklerimden memnunum" demek isteyen tasvipkâr bir gülümseme ile bakısmakta devam ediyorduk (2019: 75).

(3) "Kayınbiraderleriniz küçük mü?" diye sordum (...) Fakat birkaç dakika sonra: "Hayır, ufak değiller!" dedi. "İkisi de işe gidiyorlar." (2019: 23).

\section{c. Hepsi Sözcü̈̆̈̈̈ ile Değiștirim}

(1) Halkevinin camlarından aksederek beyaz mermer binayı kan rengi deliklere boğan günes, akasya ăgaçlarının ve çam fidanlarının üzerinde yükselen ve buğu mudur, toz mudur, ne olduğu belli olmayan duman, herhangi bir inșaattan dönen ve parça parça elbiselerinin içinde sessiz ve biraz kambur yürüyen ameleler, üstünde yer yer otomobil lastiği izleri uzanan asfalt... Bunların hepsi mevcudiyetlerinden memnun görünüyorlardı (2019: 8).

(2) Küçük Nurten bile ablasına ve dayılarına uymak için çırpınıyordu. Sonradan bu eve her gidişimde aynı şeyi gördüm (...) Sonradan, bu eve gidip geldikçe, bu çocukların hepsiyle ahbap oldum (2019: 24).

\section{d. Herkes Sözcü̈̆̈̈̈ ile Değiştirim}

(1) Boşuna yere herkesten kaçmış, boş yere bütün insanları kendimden uzaklaştırmışım; ama bundan sonra başka türlü yapabilir miyim? (2019: 43)

(2) Yaşadiğım müddetçe türlü türlü yerler gezecek, dilini bildiğim ve bilmediğim insanlarla tanışacak ve her yerde, herkeste onu, Maria Puder'i, Kürk Mantolu Madonna'yı arayacaktım (2019: 121).

\section{e. Böyle/Öyle Sözcükleri ile Değiştirim}

(1) Bir makine gibi buraya geliyor, işlerini görüyor, anlayamadı̆̆ım bir itiyatla birtakım kitaplar okuyor ve akşamları alışverişini yapıp evine dönüyordu. Ihtimal, birbirine tıpk tıpkısına benzeyen bu bir sürü günlerin ve hatta senelerin içinde, hastalık zamanlarl yegâne değişiklikti. Arkadaşların anlattı̆̆ına göre, o oldum olası böyle yaşamaktaydı (2019: 17).

(2) Onun şaşıracağını, sırrını ele vereceğimden korkacă̆ını sanmıştım. Hiç de böyle olmadl (2019: 20).

(3) Çocuk dört yaşına kadar hastanelerde ve bakımevlerinde kald, sonra büyükannesi yanma aldl. Biraz zaylf ve durgun bir klz; fakat pek sevimlidir... Siz öyle bulmuyor musunuz?" (2019: 156)

\section{f. Öteki Sözcü̈̆̈̈̈ ile Değiştirim}

(1) Bir gün gene, sırf daktiloların Raif efendiye ehemmiyet vermemeleri yüzünden geç kalmış olan bir tercüme için Hamdi, bizim odaya kadar gelmiş, oldukça sert bir sesle:

"Daha ne kadar bekleyeceğiz? (...) diye bağırmıştı.

Öteki, iskemlesinden süratle doğrularak:

"Ben bitirdim efendim! Hanımlar bir türlü yazamadılar (2019: 17).

(2) İçeri kırk yaşlarında, kesik saçları kulaklarına ve yüzüne dökülmüşs, şişmanca bir kadın girdi. Raif efendinin kulağına ĕ̆ilip bir şeyler söyledi. Öteki ona cevap vermeden beni işaret ederek:

"Daire arkadaşlarindan..." diye takdim etti. "Refikam." (2019: 22)

\section{g. Bu/Şu Önadı ile Değişstirim}

(1) Ta birbirimizi tekrar görmek ihtiyacını şiddetle duyuncaya kadar... Haydi artık Raif. Bu an gelince ben seni ararım; belki tekrar dost olur ve bu sefer daha akıllı davranırız (2019: 119).

(2) "Evet" demiştim. "En çok sevdiğinize hakikaten ve diğerlerine birer parça âşıksınız!" Maria hiç beklemediğim bir cevap vermişti:

"Şu halde niçin beni kıskanmadığınızı söylüyordunuz?" (2019: 105)

\section{h. Başka Bir Sözcükle Değiştirim}

(1) "Raif efendi sizsiniz, değil mi?" diye sormuştum (...) Bir yabancl ile karşı karşıya oturulduğu zaman âdet olduğu üzere oda arkadaşımı gizliden gizliye tetkik etmek, kaçamak 
bakışlarla hakkında ilk -ve tabii yanlış- kanaatler edinmek istiyordum (...) Ben artık gözlerimi pervasızca karşımdakine dikmiştim (2019: 14).

(2) Ben șirkete girdiğimden, yani aylardan beri, Hamdi hakkında birbirine zıt bir sürü hükümler verip duruyordum (2019: 19).

(3) Yalnız karısı, senelerden beri bir saniye bile hafiflemeyen işler ve geçim dertleriyle biraz aptallaşmışa benzeyen Mihriye hanım, kocaslyla elinden geldiği kadar meşgul oluyor, onun kendi evlatları tarafindan küçük görülmemesi, horlanmaması için gayret ediyordu (2019: 27).

(4) Ви baş, bu hasta, bu yaşlı vücudu neden buralara sürüklemişti? Raif efendinin o karanlık ve soğuk gecenin içinde nasıl yürüdüğ̈̈nü, yüzünün nasıl bir şekil aldiğını tasavvur etmek istiyordum (2019: 33).

(5) Salonda birkaç kere rast geldiğim ve uzun saçl, siyah elbiseli, kocaman boyunbağgl ressamlarla konușușundan kendisinin de ressam olduğunu anladığım genç bir kadın yanıma sokularak:

"Bu resmi pek mi merak ettiniz?" dedi. (...)

Karşımdakinin fazla laubali ve biraz alaycı gülüşü bana fena tesir etmişti (2019: 57).

(6) Hatta kadının da bu samimi hislere pek yabancı kalmadı̆̆l, elliyi geçtiği halde dinçliğini muhafaza etmiş olan bu koca bekâru yumuşak bağlarla bend etmek hususunda muayyen birtakım planları bulunduğu söyleniyordu (2019: 61).

(7) Orada bu Maria Puder'le annesine tesadüf ettik. (...) Maria pek zaylf ve halsizdi, Berlin'de ağır bir hastalık geçirdiğini söylüyordu. (...) Kı oldukça kendini toplamıştı (2019: 155).

(8) Maria Puder, benim Kürk Mantolu Madonnam, dudaklarının kenarındaki ince kıvrıntı ve siyah gözlerinin derin bakışlarıyla karşımda duruyordu (2019: 157).

\subsubsection{Eksilti}

Ögeleri eksik olan ancak kullanılmayan ögelerin zihinsel olarak tamamlanması ile anlamı bozmaması durumu için kullanılan eksilti (ellipsis), metinsellik ölçütleri içinde sıkça kullanılan bağdaştırma yollarından biridir. Anlatıcı eksiltiye tekrara düşmemek, akışı bozmamak için başvurur. En az çaba kuralı gereği tekrardan söylenmeyen tüm unsurların metnin başka bir yerinde mutlaka karşılığı bulunmaktadır. Balyemez'e göre eksiltinin hem anlam hem de yapı boyutu vardır. Eksilti, söylemin anlaşılması, iletinin alıcıya eksiksiz verilmesi bakımından anlamla; tümcedeki herhangi bir unsurun düşürülmesi bakımından da yapıyla ilişkilidir (2011: 112).

Yüzey yapıda eksik olan tüm ögeler, derin yapıda mevcuttur ve eksiltilmiş ögelerin varlığı ancak metne başından beri hâkim olan okur tarafından bilinmektedir. Eksik ögelerin metinde bıraktığı boşluklar, anlatıcının bıraktığı izlerle tamamlanmaktadır. Uzun Subaşı'ya göre gönderimsel ilişkiler gibi metinsel ilişkiler, atılan ögenin alıcı tarafından çıkarımsal olarak tamamlanmasını öngörür (2004: 31). Eksiltili anlatım, anlatımda belirsizliğe neden olmadan metin boyunca tümcelerdeki bazı sözcüklerin kullanılmaması olan bu bağdaşıklık türünde, ses düzeyinde eksiltiler, tümce düzeyinde eksiltiler, metin düzeyinde eksiltiler, pragmatik düzeyde eksiltiler, üslupbilim düzeyinde eksiltiler olmak üzere çeşitli düzeylerde ele alınmaktadır (Yılmaz, 2012: 23; Aşkın Balcı, 2018: 114). Bunlarla birlikte özne, yüklem veya tümcenin başka bir ögesinin yüzey yapıda yeniden gösterilmemesi de eksiltme yolu kabul edilebilir.

Kürk Mantolu Madonna adlı metinde yüklem, nesne, yer tamlayıcısı, özne ve diğer tamlayıcılar olmak üzere eksiltili yapılar sıkça kullanılmaktadır. Belirli bir ögenin eksik kullanımının yanı sıra özellikle soru-cevap şeklinde geçen karşılıklı konuşmalarda sorulan soruya verilen cevabın soruda yer alan ögelerin birebir karşılıkları olmadığı yerine değiştirim yoluyla başka sözcük ve ögelerin kullanıldığı örneklere de metinde rastlanmaktadır. Bu çalışmada bu durum, tümce eksiltisi kavramı ile karşılanmıştır.

\section{a. Yüklem Eksiltisi}

(1) Yerinden kalkar gibi bir hareket yapt,, hemen doğruldum ve elimi uzatarak:

"Bana müsaade!" dedim (2019: 11).

(2) Aylardan beri süren işsizlik, buradan çıkınca nereye gideceğimi, nerede iş arayacă̆ımı bilmemek... (2019: 13).

(3) "Beni burada mı beklediniz? Ne zamandan beri?" dedi.

"Bir saatten beri!" (2019: 86) 


\section{b. Yer Tamlayıcısı Eksiltisi}

(1) Dışarı çıktı̆̆ım zaman ortalık adamakıllı kararmış, sokak lambaları yanmıştı (...) A Ăır ăğır yürü̈düm (2019: 12).

(2) Koltuğundan kalkmadan elini uzattı. Sokuldum ve teşekkür ettim (2019: 13).

(3) Hatta bugünkü gezintimizden memnunum. Herhalde memnunum... (2019: 92)

\section{c. Nesne Eksiltisi}

(1) "Ben size bu işin hepsinden acele olduğunu söylemedim mi?"

"Evet efendim, ben de onlara söyledim!" (2019: 18).

(2) Hamdi yarına kadar tercüme edilecek bir yazıyı hademe ile göndermek istiyordu: "Bana ver, hem ziyaret etmiş olurum" dedim (2019:20).

\section{d. $\ddot{O}_{z \text { ne Eksiltisi }}$}

(1) (Ben) $)^{6}$ Büyük salonun kapıya yakın bir duvarının önünde birdenbire durdum (2019: 52).

(2) “(Siz) Sahiden böyle bir anneniz olmasın ister miydiniz?” dedi (2019: 58).

(3) Ve (Maria Puder) derhal küçük bir kahkaha attı (2019: 58).

(4) Türkiye'ye geldikten sonra (biz) onunla sik sık mektuplaştık (2019: 143).

(5) Belki de bende bu işe fazla bir heves görmediklerinden, (onlar) boşuna yere vakit ziyan etmemek için böyle yaptılar (2019: 50).

\section{e. Tümce Eksiltisi}

Tümce eksiltisinin görüldüğü örnekler çoğunlukla karşılık konuşmalarda yer almaktadır. Tümce eksiltisi aynı zamanda değiştirim örneği de sergilemektedir. Bir soruya verilen cevap, sorudaki tüm ögeleri kapsamamakla beraber farklı bir sözcük veya ögeyi içerecek biçimde uzun ya da kısa biçimde olabilmektedir. Türkçede bunun için evet, hayır gibi onay sözcükleri sıkça kullanılmaktadır. Bu gibi sözcüklerle bir önceki soru tümcesinde yer alan tüm sözcükler tekrarlanmak ya da karşılanmak zorunda değildir. Gönderici, alıcının diğer ögeleri zihninde tamamlayacağını bilmektedir. Evet-hayır'lı cevapların yanı sıra yine bir sorunun karşılığında başka bir cevabın verilmesi eksilti örneği olduğu gibi aynı zamanda değiştirim örneği de kabul edilebilir. Metin bu gibi tümcelere sayıca fazla örnek teşkil etmektedir.

(1) "Hep bankada misin?" diye sordu.

"Hayır, ayrıldım!" dedim.

Hayret etti:

"Nereye girdin?"

Istemeye istemeye cevap verdim:

"Açıktayım!" (2019: 9).

(2) "Bir yere mi gittiniz?"

"Hayır... Şöyle azıcık dolaşmak istedim... Ne bileyim... İçim sıkıldı galiba..." (2019: 31).

(3) "Orada, gözün içinde ne varsa hepsini getir!” dedi. "Ne varsa... Bizim hanım galiba benim bir daha şirkete gidemeyeceğimi sezdi (2019: 37).

(4) "Bugün nereleri gezdiniz?” dedi.

"Hiç... Dolaştım, sonra modern ressamların bir sergisini gezdim!” diye cevap verdim (2019: 53).

(5) "Türk müsünüz?"

"Evet!" (2019: 57)

(6) "Demek bir anneniz var?"

"Sizin gibi!" (2019: 75)

(7) "Neden bana bu kadar dikkatli bakıyorsunuz?" dedi (...)

“Ístemiyor musunuz?” dedim (2019: 87).

\footnotetext{
${ }^{6}$ Tümcede yer almayan özneler örneklerde parantez içinde gösterilmiştir.
} 


\subsubsection{Băglaçlar}

Bağlama ögeleri yani bağlaçlar (conjunction), eş görevli sözcükleri, sözcük öbeklerini ve tümceleri birbirine bağlamakla görevli birimlerdir. Sözün akışını sağlamak, ilgi kurmak, sebep-sonuç bildirmek, amaç göstermek, verilen tüm bilgileri önce veya sonraki bilgilere bağlamak, özetlemek gibi amaçlarla kullanılan bağlaçlar Balyemez'e göre, alıcıyı yargılara odaklayacak ve metnin oluşumuna, anlamlandırılmasına katkıda bulunacaktır (2011: 170).

Bozok, bağlaçları yüzey yapı olarak değerlendirilen bağdaşıklık ögeleri arasında sıralamakla birlikte metinlerin anlamına sundukları kapsamında derin yapı olarak değerlendirilen tutarlılık ile anlamsal bütünlük noktasında örtüştüğünü dile getirmektedir (2019: 24). Bir metinde kullanılan paragraflarda geçen her tümcenin bir önceki ve bir sonraki tümce ile arasında söz dizimsel ilişki kurması gerektiği gibi her şeyden önce anlamsal ilgi de kurmak zorundadır. Tam tersi düşünüldügünde paragraf birbirinden kopuk hatta alakasız sözcükler ve tümceler yığını haline gelecektir. Bu ilgi, yalnızca bir paragrafı oluşturan sözcükler ve tümceler arasında değil, aynı zamanda paragraflar arasında da geçerli olmalıdır. Hem paragraf içindeki hem de paragraflar arasındaki anlamsal bağdaştırma ilgisini kuracak olan ögeler de bağlaçlardır.

Halliday ve Hasan çalışmalarında basit veya birleştirme belirteçleri, diğer birleşik belirteçler ve diğer gönderim ögeleriyle kurulmuş ilgeç ifadeleri olarak yapısına göre incelediği (1976: 231) belirteçleri, bağdaşıklık kapsamında dört kategoride ele almaktadır. Dört tür bağlayıcı ögeden yani bağlaçtan bahsetmektedir.
a. Ekleyici (additive)
b. Çelistirici (adversative)
c. Nedenleyici (causal)
d. Zaman bildiren (temporal) (242-243).

\section{a. Ekleyici Bağlaçlar}

(1) "Nasıl? İnşallah artık bitti ya?" diye iğneli geçmiş olsunlarla karşılarlardı. Bununla beraber, artık ben de Raif efendiden sıkılmaya başlamıştım. Şirkette pek fazla oturduğum yoktu (2019: 17).

(2) Ben de sizin gibi tabiatı çok severim, hatta diyebilirim ki insanlardan ne kadar uzak kaldiysam tabiata o kadar sokuldum (2019: 97).

(3) Yaşamak, tabiatın en küçük kımıldanışlarını sezerek, hayatın sarsılmaz bir mantık ile akıp gidişini seyrederek yaşamak; herkesten daha çok, daha kuvvetli yaşadiğını, bir ana bir ömür kadar çok hayat doldurduğunu bilerek yaşamak... Ve bilhassa bütün bunları anlatacak bir insanın mevcut olduğunu düşünerek, onu bekleyerek yaşamak... (2019: 85)

(4) Onu kolundan tutup, bir kanepeye oturturken veya sirtına ince bir hirka birakırken, hayatımı bir başka insana vakfetmiş olmanın nihayetsiz saadetini duyuyordum (2019: 135).

(5) Bir kadın, trenin penceresinden dışarl bakabilir (...) bu minimini hadise dünyanın en güzel gözlerinden birini kör edebilirdi. Yahut bir kiremit, hafif bir rüzgârla yerinden oynayarak, devrin gipta ettiği bir kafayı parçalayabilirdi (2019: 137).

\section{b. Çeliştirici Bağlaçlar}

(1) Ne zaman kendimle baş başa kalsam, Raif efendinin saf yüzü, biraz dünyadan uzak, buna rağmen bir insana tesadüf ettikleri zaman tebessüm etmek isteyen bakışlarl gözlerimin önünde canlaniyor (2019: 7).

(2) Raif efendinin saf yüzü, biraz dünyadan uzak (...). Halbuki o hiç de fevkalade bir adam değildi (2019: 7).

(3) Sadece, kalkıp, kimseye haber vermeden gitmeyi ve bu sikıntıl vaziyetten kurtulmayl düşündüm. Fakat bu sırada beyaz önlüklü, başörtülü, yaşlı bir köylü kadın, yamalı siyah çoraplarıyla, hiç ses çıkarmadan kahve getirdi (2019: 10).

(4) "Bırak böyle şeyleri canım!" diyerek pratik hayatın muvaffakiyetlerinden, edebiyat gibi boş şeylerin mektep sıralarından sonra ancak zararlı olabileceğinden bahsetti (2019: 11).

(5) Birçok vesilelerle, onun hisleri kütleşmiş bir adam olmadiğını fark etmiştim. Hatta bunun aksine olarak çok alıngan, gayet ince görünüşlü ve dikkatliydi (2019: 29). 
(6) Kırık bir tuğla parçası kadar şekilsiz kristal vazolar (...) nihayet, mücrimler albümünden alınmışa benzeyen korkunç portreler... Ama ne olsa insan eğleniyordu (2019: 51).

\section{c. Nedenleyici Bağlaçlar}

(1) Yalnız o, asıl aradı̆̆ını bulamamakla beraber, bendeki diğer birçok tarafların kendisi için feda edilemeyecek kadar klymetli olduğunu görüyor, bunun için, kendisinden uzaklaşmama sebep olacağını zannettiği şeyleri yapmaktan çekiniyordu (2019: 107).

(2) Ömrümüzden bir sene geçtiğini göstermesi bile o kadar mühim değil; çünkü ömrümüzü senelere ayırmak da insanların uydurmast... (2019: 108)

(3) Bunları düşünmekten kurtulmak için bir hareket yaptım. Mademki o karşımdaydı ve benimle konuşuyordu, artık başka şeylerle meşgul olmak lüzumsuz ve manasızdı (2019: 71).

(4) Her şey, her şeyi olduğu gibi kabul etmekteydi. Şu halde bana da yapacak başka bir şey kalmiyordu (2019: 9).

\section{d. Zaman Bildiren Bağlaçlar}

(1) "Bacanak Iktisat Vekâleti'ndedir, birer işe yerleştirdi. Okumadilar, ellerinde bir orta mektep şahadetnamesi bile yok!" Sonra, birdenbire sözünü keserek sordu: "Tercüme için bir şey mi getirdiniz?" (2019: 23)

(2) Küçük Nurten bile ablasına ve dayılarına uymak için çırpınıyordu. Sonradan bu eve her gidişimde aynı şeyi gördüm (2019: 24).

(3) Peki makamında başımı salladım. Ona birçok şeyler söylemeyi gündüzden tasarlamıştım. Fakat bunların hiçbiri aklıma gelmiyor, kafamdan yepyeni şeyler geçiyordu. Nihayet karar verdim ve rastgele konuşmaya başladım (2019: 101).

(4) Çaresizlikten gözlerimin yaşardığım fark ettim. $\boldsymbol{O}$ zaman onun çehresinde rahat bir gevşeme oldu (2019: 103).

(5) Konuşurken ăgzından yabancı bir kelime çıktı̆̆ı, herhangi bir zaman dil bildiğinden bahsettiği duyulmamış; elinde veya cebinde ecnebi gazete ve mecmualar görülmemişti. Hulasa, bütün varlıklarlyla: "Biz Frenkçe biliriz!" diye haykıran insanlara benzer bir tarafi yoktu (2019: 15).

\subsubsection{Sözcü̈ksel Bă̆dașıklık}

Aynı, benzer ve zıt anlamlı sözcüklerin kullanımı veya alt-üst anlamlılık ilişkisi bulunan sözcüklerin kullanımı ile metinde sağlanan bağdaştırma yolu, sözcüksel bağdaşıklık (lexical cohesion) olarak bilinmektedir. Adıl ve eklerle sağlanan gönderim ve öyle, böyle gibi belirli kapsayıcı birimlerle yerini tutmayı gösteren değiştirim türlerinden farklı olarak sözcüksel bağdaşıklıkta genel bir sözcük yine bir sözcükle aynı ya da benzer anlam alanlarını çağrıştırmak üzere kullanılmaktadır. Uzun'a göre sözcüksel bağdaşıklık metinde bütünlüğü ve sürekliliği sağlayan temel bağdaşıklık unsurlarından biri olarak değerlendirilir. Okur, metinde sözcüksel bağdaşıklığın tespiti ile belirlenen anahtar sözcükler sayesinde metnin içeriği, konu ve alt konularına dair ipuçlarına ulaşabilir (2018: 725).

Sözcüksel bağdaşıklık tekrarı diğer bir deyişle yinelemeleri içermektedir. Aşkın Balcı'ya göre yineleme ile metindeki tümce ve tümce grupları arasındaki ilişkiler incelenmektedir (2018: 77). Özkan'ın söz varlığı düzenlemesi olarak gördüğü bu bağdaştırma türü, aynı kökten yapılmış sözcük yinelemelerini de içermektedir (2004: 179).

Halliday ve Hasan, bağdaşıklığı sağlayan tekrar unsurlarını aşağıdaki gibi siniflandirmaktadır (1976: 279):

a. Aynı sözcükle tekrar (the same world)

b. Eş veya Yakın Anlamlı sözcük tekrarı (a synonym or near-synonym)

c. Üstanlamlı sözcükle tekrar (a superordinate)

d. Genel anlamlı bir sözcükle tekrar (a general word).

Halliday ve Hasan, söz konusu tasniflerine zıt anlamlı ve eşdizimli sözcükler de eklenebilir. 


\section{a. Aynı Sözcüğ̈̈̈n Tekrart}

Karş1lıklı konuşmaların sıkça görüldüğü metinde özellikle bu konuşmalar esnasında sözcük tekrarlarına gidildiği fark edilmektedir. Bu şekilde anlatıcı konuşturduğu kahramanın telaşlarını, isteklerini, bir durum karşısında ne kadar emin olduğunu göstermek için sözcük tekrarlarına başvurmaktadır.

(1) Raif efendi düşündü, düşündü; sonra, sanki nihayet bir çare bulmuş gibi başını sallayarak:

"Gider, gider!” dedi ve önüne baktı (2019: 23)

(2) Bu takdirde birkaç sene, hatta on on iki sene geriye gitmek lazım... (2019: 44)

(3) Şiddetle reddetti:

"Hayır! Hayır!.. Hep aynı fikirdeyim..." (2019: 88)

(4) "Ne yapayım? Ne yapayım? Başka türlü olamıyorum işte!" dedi (2019: 93).

(5) "Nasıl? Bu geceden memnun musun? Eğlendin mi? Ah, ben çok eğlendim, o kadar, o kadar eğlendim ki..." (2019: 112)

(6) "Evet... Ben böyleyim işte...” diyordu. "Raif... Sevgili Raif...

Ben böyleyim işte... Dememiş miydim?.. Bir günüm bir günüme uymaz diye... (2019: 113)

(7) "Tabii... Tabii!" dedi. "Tabii sizi seviyorum. Hem çok seviyorum... Başka türlü olmasına imkân var mı?.. Herhalde seviyorum... Muhakkak seviyorum. Fakat neden şaşırıyorsunuz? (2019: 115)

(8) Sokakta rastgele yürümeye başladım. Ortalık tenha, dükkânların çoğu kapalıydı. Cenup istikametinde gidiyordum. Yanımdan, buğulu camlartyla tramvaylar, omnibüsler geçiyordu. Yürü̈düm... Kararmış yüzlü evler, parke kaldırımlar başladı... Gene yürrüdüm... Demiryolu köprülerinin altından, buz tutmuş kanalların üstünden yürüddüm... Hep yürrüdüm. Saatlerce yürüdüm (2019: 119).

\section{b. Eş/Yakın Anlamlı Sözcüklerin Tekrarı}

Eş anlamlı ya da yakın anlamlı sözcükler metinde akıcılığı sağlamak amacıyla anlatıcılar tarafından sıkça kullanılmaktadır. Ancak incelenen bu metinde eş anlamlı sözcüklerden ziyade yakın anlamlı sözcüklerin daha çok kullanıldığı dikkat çekmektedir. Aşağıda da yakın anlamlı sözcüklerle yapılan bağdaştırma örneklerinden bazıları yer almaktadır:

(1) Hep aynı kapalı, sessiz insan olarak kaldı (2019: 24).

(2) (...) Bu Madonna'nın yüzü, başını tutuşu, bakışlarında ve dudaklarında apaçık görünen melal ve kirgınlık ifadesi aynen dün gördüğ̈̈m tabloya benziyordu (2019: 54).

(3) Bir akşam evvel sarhoş halimde, alaycı bir tebessümle bana gözlerini diken bir kadını yürüyüşünden tanımama imkân var mıydı? Bakalım dün akşam onu sahiden görmüş müydüm? (2019: 67)

(4) Her hususta doğru ve salim hükümler veren bu kadının, hayattaki acı tecrübelerine, muhitin bozucu tesirlerine tabi olarak böyle düşündüğü muhakkaktı (2019: 92).

\section{c. Zıt Anlamlı Sözcük Kullanımı}

Zıt anlamlı sözcüklerin kullanımı, özellikle eserde geçen kahramanların ruh hallerinin veya dış görünümlerinin tasvirinde görülmektedir. Bunun yanı sıra bir durumun izahında da karşıt anlama sahip sözcükler, bağdaşıklığı sağlamak amacıyla metinde yer almaktadır.

(1) Bütün basit insanlarda olduğu gibi, kederden sevince, heyecandan sükûnete geçiyor ve bütün kadınlar gibi her şeyi çabucak unutuyordu (2019: 37).

(2) Kaşları ne pek kalın, ne pek ince, fakat biraz kisaydl; koyu kumral saçları, köşeli ve oldukça geniş alnını çevreleyerek aşağı doğru uzanıyorlar ve yabankedisinin tüylerine karışıyorlardı (2019: 52).

(3) Daha ziyade klasiklerin yolunda yürümek istediği anlaşılan ressam kadının, hayret verecek kadar büyük bir ifade kabiliyetine malik olduğu, kendi portrelerini yapan sanatkârlartn çoğunda görülen "gü̈zelleştirme" veya "inadına çirkinleş̧irme" temayüllerinin onda bulunmadı̆̆ söyleniyor (...) (2019: 54).

(4) Hiçbirinde tek veya çift olarak oturan ve dansa çıkmayan kimse yoktu (2019: 67). 
(5) Ne kuzuların ă̆zından vahşi kurt dişlerinin sırıttığını gördüm (2019: 79).

(6) Darılmak, tekrar barışmak, bunlar beni muhakkak ki memnun edecek... (2019: 94)

\section{d. Genel-Özel Anlam İlişkisi Bulunan Sözcüklerin Kullanımı}

Genel ve özel anlam ilişkisi, bir sözcügün gösterdiği varlığın dâhil olduğu alt ya da üst kümeyi belirtmektedir. İçerme ve kapsama ilişkisi olarak da yorumlanabilecek olan olgu, taranan metnin akrabalık durumlarını gösteren parçalarında kendini göstermektedir. Buna göre aşağıdaki iki örnek tümce "karı" ve "kızlar" sözcüklerinin "akrabalar" sözcügünün işaret ettiği kümenin alt kümesi olduğunu, bir sonraki tümcede yer alan "kadın" sözcügünün de "mahlûk" sözcügünün kodladığı genel varlık kümesine dâhil olduğunu göstermektedir.

(1) Karlsl, kızları, akrabaları dururken, benim onlardan fazla alaka ve teessür göstermeye hakkım olmadiğını düşündüm (2019: 38).

(2) Kadın, benim için, muhayyilemi kamçılayan (...) maddilikten uzak, yaklaşılmaz bir mahlukktu (2019: 55).

\section{e. Eşdizimli Sözcüklerin Kullanımı}

Belirli bir dizge içinde sık kullanılma eğilimi gösteren en az iki sözcügün birlikteliğine eşdizimlilik denmektedir. Sözcügün eşdizimli olma durumu bağlama göre şekillenmektedir. Eşdizimlilik terimi ilk defa kullanan Firth'e göre bu kavram, sözcüğün içerisinde yer aldığı tümcede soyutlanan ve sözcüğ̈̈n anlamsal tanımından ayrılan bir anlamlandırma işidir (1951: 123). Bir sözcük, metinde anlamsal olarak ilişki kurduğu eş, yakın, altanlam-üstanlam ilişkisinin bulunduğu veya çağrışımsal etkileri bulunan sözcük ya da sözcüklerle sıklıkla bir araya gelmektedir. Örneğin hırsız sözcüğü çal- eylemini; aşk sözcüğü, sevgi, sevgili gibi başka sözcükleri çağrıştırmaktadır. Çağrışım ne kadar kuvvetli olursa sözcügün eşdizimlisi olan sözcükle bağı da o oranda kuvvetli olmaktadir.

Sabahattin Ali'nin taranan eserinde, eşdizimlenmiş sözcüklerin hem sayıca fazla olduğu hem de eşdizimli sözcüklerin kullanıldığı tümce ve paragrafların da azımsanmayacak oranda olduğu dikkat çekmektedir.

(1)Sabahlart tam vaktinde geliyor, öğle yemeğini odasında yiyor, akşamlart, ufak tefek alı̧̧verişlerini yaptzktan sonra hemen evine gidiyordu (2019: 16).

(2) Raif efendinin yattı̆̆ odaya girince büsbütün şaşırdım. Burası evin diğer taraflarına hiç benzemiyen, adeta bir leyli mektep yatakhanesi, veya bir hastane koğuşu gibi yan yana bir sürü beyaz karyolaların dizili durduğu kü̧̧ük bir odaydı (2019: 21).

(3) Sıcak bastı... Önümü açtım... Hava da rüzgârlıydı... Biraz da kar sepeliyordu... (2019:

(4) Bazı mıntakalar ecnebi kuvvetleri tarafindan işgal ediliyor, birdenbire türeyen bir sürü çeteler, türlü türlü namlar altında, bazen düssmana karşı cephe kurarak, bazan köyleri soyarak faaliyet gösteriyor; dün bir kahraman olarak ismi ă̆ızdan ă̆ıza dolaşan bir sergerdenin bir hafta sonra tenkil edildiği ve ölüsünün Edremit'te Konakönü meydanında asılı durduğu ilan ediliyordu (2019: 44).

(5) Ressamın sergide yalnız tek bir eseri, kendi portresi bulunduğu anlaşıllyyordu (2019: 53).

(6) Salon birdenbire karard. Yalnız orkestranın bulunduğu yerde hafif bir lşık vardı. Dans edilen yer boşalmıştı. Biraz sonra ă̆ır bir müzik başladı. Sazların arkasından doğru ince bir keman sesi duyuldu. Ses yavaş yavaş yaklaşlyordu (2019: 67).

(7) Gökyüzü açıktı ve garpta, ufka yaklaşmış bulunan ince bir hilal vardı (2019: 77).

\section{SONUÇ}

Tümce üstü ya da tümce ötesi birim olan metin, söz dizimsel boyutunun yanı sıra anlambilimsel yönüyle pek çok çalışmanın konusu olmuştur. Söz konusu çalışma alanlarından biri olan metindilbilim, metin denilen yapının özelliklerini belirlemeyi, bir tümce ya da sözceyi metin boyutuna taşıyan ölçütleri sunmayı, bir metni diğerlerinden ayıran nitelikleri araştırmayı hedef almaktadır. Metindilbilimde, bir söz dizimsel parçayı metin olarak kabul edebilmek için Beaugrande 
ve Dressler (1981) tarafından ortaya atılan yedi metinsellik ölçütü yer almaktadır: bağdaşıklık, tutarlılık, niyet, kabul edilebilirlik, durumsallık, metinlerarasilık ve bilgisellik.

$\mathrm{Bu}$ çalışmanın temel konusunu oluşturan metinsellik ölçütlerinden bağdaşıklık, metnin yüzey yapısına yansıyanla derin yapısında bulunan bilgilerin özellikle anlamsal bağlantısını gösteren özelliktir. Bir metinde, metindeki yapıları bağdaştırma yolları ile ilgili farklı sınıflandırmalar mevcuttur. Bunlardan biri de Halliday ve Hasan'ın (1976) çalışmasında yerini almıştır. Buna göre bir metinde bağdaşıklık; gönderim, değiştirim, eksilti, bağlaçlar ve sözcüksel bağdaşıklıkla sağlanmaktadır.

Sabahattin Ali'nin Kürk Mantolu Madonna adlı eserinde bağdaşıklığın incelendiği bu çalışmada, bağdaşıklık türlerinden gönderimin çoğunlukla adıllarla ve özellikle şahıs ve işaret adıllarıyla sağlandığı görülmektedir.

Diğer bir bağdaşıklık türü olan değiştirim, bir tür yerine geçme işlemidir. Söz konusu bağdaştırma türü metinde öyle/böyle, biri/birbiri, ikimiz/ikisi, hepsi, herkes, öteki gibi adıllarla beraber başka sözcük ya da sözcük öbekleriyle karşılanmaktadır.

Eksilti, yine yüzey yapıda görünmeyen ancak derin yapıda ve alıcı tarafından varlığı bilinen yapılara işaret eder. Metinde yüklem, nesne, yer tamlayıcısı, özne ve tümce eksiltisi şeklinde varlığını göstermektedir. Tümce eksiltisi aynı zamanda değiştirim türüne de örnek vermektedir.

Bağlaçlarla sağlanan bağdaşıklık, metnin akıcılığını sağlamak ve tümce ile paragrafları birbirine bağlamak amacıyla anlatıcı tarafından söz konusu metinde sıkça tercih edilmiştir. Kürk Mantolu Madonna adlı eser, Halliday ve Hasan'ın (1976) bağlaç tasnifi olan ekleyici, çeliştirici, nedenleyici ve zaman bildiren bağlaç türlerinin her birine örnek sunmaktadır. Diğer kategorilere oranla çeliştirici bağlaçların daha sık kullanıldığı görülmektedir.

Sözcüksel bağdaşıklık ise metinde aynı sözcüğün tekrarı, eş/yakın anlamlı sözcük tekrarı, üstanlamlı sözcükle tekrar, genel anlamlı sözcükle tekrar, zıt anlamlı sözcükle tekrar ve eşdizimlilik şeklinde görülmektedir. Çalışmada genel anlamlılık ve üstanlamlılık ölçütleri tek bir kategoride birleştirilmiştir.

\section{KAYNAKÇA}

Akçataş, A. (2001). Dokuzuncu Hariciye Koğuşu Romanı Üzerine Bir Metin Dil Bilim İncelemesi, Yayımlanmamış Doktora Tezi, Pamukkale Üniversitesi Sosyal Bilimler Enstitüsü, Denizli.

Aksan, M. ve Aksan, Y. (1991). Metin Kavramı ve Tanımları. Dilbilim Araştırmaları Dergisi, 2, 90-104.

Akşit, E. (2019). Abdullah B. Revâha'nın Hz. Hamza'nın Şehadetine İlişkin Şiirinde Bağlaşıklık Öğeleri. Ballkesir Üniversitesi İlahiyat Fakültesi Dergisi, 5(1), 126-156.

Aşkın Balcı, H. (2006). Metindilbilim Açısından Bir Çözümleme. Erciyes Üniversitesi Sosyal Bilimler Enstitüsü Dergisi, 1(21), 191-204.

Aşkın Balcı, H. (2018). Metindilbilimin ABC'si, İstanbul: Say Yayınları.

Aydoğan, B. (2014). Sabahattin Ali'nin Yaşamı ve Yapıtlarına Genel Bir Bakış, Nurettin Demir ve Faruk Yıldırım (Ed.), Prof. Dr. Mehmet Özmen Armağanı (s. 61-94), Adana: Çukurova Üniversitesi Basımevi.

Balyemez, S.(2011). Dede Korkut Hikâyelerinin Metin Dil Bilimsel Yapısl, Yayımlanmamış Doktora tezi, Gazi Üniversitesi Sosyal Bilimler Enstitüsü, Ankara

Beaugrande, R. A. de ve Dressler, W.g (1981). Introduction to Text Linguistics, New York: Longman Group Company.

Bozok, L. (2019). Ortaokul 8. Sinıf Türkçe Ders Kitaplarındaki Metinlerin Bağdaşıklık ve Tutarlllık Yönünden İncelenmesi, Yayımlanmamış Yüksek Lisans Tezi, Hatay Mustafa Kemal Üniversitesi Sosyal Bilimler Enstitüsü, Hatay.

Coşkun, Eyyup (2005). İlköğretim Öğrencilerinin Öyküleyici Anlatımlarında Bağdaşıkllk, Tutarlllık ve Metin Elementleri, Yayımlanmamış Doktora Tezi, Gazi Üniversitesi Eğitim Bilimleri Enstitüsü, Ankara.

Dilidüzgün, Ş. (2008). Türkçe Öğretiminde Metindilbilimsel Bağlamda Uygulamalı Bir Yaklaşım, Yayımlanmamış Doktora Tezi. İstanbul Üniversitesi Sosyal Bilimler Enstitüsü, İstanbul.

Enginün, İ. (2005). Cumhuriyet Dönemi Türk Edebiyatı, İstanbul: Dergâh Yayınları. 
Firth, J. R. (1957). Modes of Meaning. Papers in Linguistics 1934-1951, Newyork: London-Oxford University Press.

Halliday, M. A. K. ve Ruqaiya, H. (1976). Cohesion in English, London: Longman Group UK Limited.

Girmen, P. (2011). Metin Üretimi, Ş. Dilek Belet (Ed.), Türkçe Sözlü Anlatım (s. 43-61), Eskişehir: Anadolu Üniversitesi Açıköğretim Fakültesi Yayını.

Kala, H. (2018). Ömer Seyfettin Hikâyelerinde Metindilbilimsel Bağdaşıklık, Yayımlanmamış Yüksek Lisans Tezi, Ağrı İbrahim Çeçen Üniversitesi Sosyal Bilimler Enstitüsü, Ağrı.

Onursal, İ. (2003). Türkçe Metinlerde Bağdaşıklık ve Tutarlılık, Ayşe Kıran, Ece Korkut ve Suna Ağıldere (Yay. Haz.), Günümüz Dilbilim Çalışmaları, İstanbul: Multilingual Yayınları.

Oraliş, M. ve Şeyda, O. (1992). Metinbilimsel yaklaşımla Yazınsal Bir metni Çözümleme Denemesi, Dilbilim Araştırmaları, 37-51.

Özkan, B. (2004). Metindilbilimi, Metindilbilimsel Bağdaşıklık ve Haldun Taner’in “Onikiye Bir Var” Adlı Öyküsünde Metindilbilimsel Bağdaşıklık Görünümleri. Çukurova Üniversitesi Sosyal Bilimler Enstitüsü Dergisi, 13(1), 167-182.

Parlak, H. (2009). Kutadgu Bilig'in Metindilbilimsel Yapısı, Yayımlanmamış Doktora Tezi. Gazi Üniversitesi Sosyal Bilimler Enstitüsü, Ankara.

Sabahattin Ali (2019). Kürk Mantolu Madonna, Ankara: Venedik Yayınları.

Seçkin, P.; Arslan, N. ve Ergenç, S. (2014). Bağdaşıklık ve Tutarlılık Bakımından Lise ve Üniversite Öğrencilerinin Yazılı Anlatım Becerileri, Uluslararası Türkçe Edebiyat Kültür Eğitim Dergisi, 3(1), 340-353.

Torusdağ, G. ve Aydın, İ. (2019). Metindilbilim ve Örnek Metin Çözümlemeleri, Ankara: Pegem Akademi Yayınları.

Uzun, M. (2018). Edebî Metinlerde Kişisel Çağrışıma Dayalı Bağdaşıklık Unsurları. IX. Uluslararası Dünya Dili Türkçe Sempozyumu Bildiri Kitabı içinde (s. 721-734), Malatya.

Uzun Subaşı, L. (1995). Orhun Yazıtlarının Metindilbilimsel Yapısı, Ankara: Türk Dilleri Araştırma Dizisi 7.

Uzun Subaşı, L. (2004). Metin Üretimi. Türkçe Yazılı ve Sözlü Anlatım içinde (s. 21-38), Eskişehir: Anadolu Üniversitesi Açıköğretim Fakültesi Yayını.

Yılmaz, Ö. (2012). 11. Sınıf Öğrencilerine Ait Öyküleyici Metinlerin Bağdaşıklık ve Tutarlılık Açısından Incelenmesi. Yayımlanmamış Yüksek Lisans Tezi. Bülent Ecevit Üniversitesi Sosyal Bilimler Enstitüsü, Zonguldak. 


\section{Purpose}

\section{EXTENDED SUMMARY}

Textlinguistics, which takes its material as text and keeps the text above the sentence, is a linguistic discipline that aims to determine what the text should be and what distinguishes it from the sentence, writes and analyses the society based on the text. The main purpose of textlinguistics is the necessity of interpreting larger units to determine an emotion, thought or judgment. The greatest service of textlinguistics is to provide the criteria necessary to call a syntactic component text. For this reason, Beaugrande and Dressler (1981) tried to reveal the criteria for textuality in their studies. Accordingly, the researchers talk about seven criteria for textuality: cohesion, coherence, intentionality, acceptability, situationality, intertextuality, informativity. It is called cohesion when the surface structures are shared or quoted among separate texts. The cohesion of a single text is only apparent given the general discourse. Intentionality and immediate feedback of the text are shown as acceptability. Situationality has a specific role in the text, and intertextuality indicates the relationship of a text with other texts. Informativity is when the speaker meets the information in direct proportion with the demand from the text. Cohesion and coherence from the mentioned criteria are text-centered; situationality, informativity, acceptability, intentionality and intertextuality can be evaluated in two different categories in terms of being user-centered.

In this study, Sabahattin Ali's Kürk Mantolu Madonna, which has gained an important place in Turkish literature in recent period, has been studied in a text linguistic context. Only the cohesion criterion, which is mentioned above, was tried to be examined in detail.

It is called cohesion to the textuality criterion, which shows the connection between the information shown in the surface structure of the text and the information in the deep structure in a grammatical or semantic way. A text carries traces from its narrator in the surface structure, including information, experience, and cultural elements, and reflects inter-information overlaps within itself. In order for the message to be conveyed by the narrator to be appropriate and acceptable for the intention, it must also meet some criteria. Otherwise, the reader will not be able to perceive the message to be given, and there will remain gaps in her/his mind. There are different ways to achieve cohesion in a text. Halliday and Hasan (1976) gathered these ways in their study under the following headings: reference, substitution, ellipsis, conjunction and lexical cohesion.

\section{Methodology}

In this study, qualitative research method and document analysis were used. First of all, what is wanted to be explained with concepts such as text and textlinguistics is explained. For this, a large literature review was made. Then the concept of cohesion, which is one of the criteria for textuality, is explained. Examples of selected text to support theoretical knowledge are given by explaining ways of making them compatible. In the study of Sabahattin Ali's Madonna in a Fur Coat, the text was scanned in terms of reference, substitution, ellipsis, conjunction and lexical cohesion and a representative number of samples were included in the study. At the end of each example, the publication year of the work and the page number where the sample sentence is quoted are given in parentheses.

\section{Findings}

In this study, it has been tried to determine what elements are used to ensure author's compatibility. Accordingly, it was first determined what the reference and the elements in the reference were. The narrator considers it appropriate to substitute other elements for replacing what he said earlier, since repeating the same word, phrase, or phrase makes it difficult for the reader to understand, distorts fluency in reading, and disrupts what the text wants to convey. In the reference, where the pronoun, adjective or noun is a substitute of the word to meet the same concept, the reference is categorized as a preliminary or post-submission according to the location of the item in the text. It is seen that especially in the researched text, personal pronouns and demonstrative pronouns are frequently used. The use of third singular and first plural pronouns is common compared to other pronouns. The use of $b u$ and $o$ demonstrative pronouns is also more common than other demonstrative pronouns. However, the text provided with the adjective $b u$ and $o$ is also 
encountered. In addition to word types, possessive suffixes, belonging suffix and case suffix (-dAn) are preferred by the narrator in order to refer, both for pre and post reference. Another type of cohesion, substitution, is one of the items in the text to cover or replace the other with another unit. The difference of the substitution from the reference is that the item being met can replace a situation rather than an asset. With the pronoun and adjective biri/birbiri, ikimiz, hepsi, herkes, böyle/öyle, öteki, $b u / s u$ in the researched text, it is replaced with another word or phrase.

A ellipsis is an operation performed by the receiver with items whose cavities are known and filled in, although they are not included in the sentence. However, the cavities are mentally filled by the recipient. In the ellipsis made to save the text from repetition and boring, sentence ellipsis is frequently encountered in question-answer conversations as well as subject, predicate, and complementary ellipses. In the case of sentence ellipsis, the sentence replaces another sentence.

Conjunctions are also among the common cohesion elements in the text. Some of the conjunctions classified within the scope of cohesion by Halliday and Hasan (1976) are included in the text like this: Additive, adversative, causal and temporal conjunctions.

The last of the ways of cohesion, lexical cohesion, appears in different ways in the text. These include the repetition of the same word, repeat synonym word, opposite word, general-specific word repetition and use of collocations.

\section{Conclusion and Discussion}

In this study, reference, substitution, ellipsis, conjunction and lexical cohesion which are elements of cohesion, were studies in Sabahattin Ali's Madonna in a Fur Coat. Accordingly, it is seen that pronouns are frequently used especially for reference and substitution. The decrease is mostly seen in mutual conversations and in the question and answer sections. Sentence, subject and predicate ellipses are used more than other types. It is noteworthy that contradictory conjunctions are used more often than other types. Lexical cohesion is used as collocation rather than word repetitions. This seems to be the preferred way for the narrator to make his narrative effective and to ensure coherence. 